\title{
ANTIMICROBIAL RESISTANCE IN BACTERIA ISOLATED FROM TROPICAL COASTAL WATERS OF PENINSULAR MALAYSIA
}

\author{
Kian Giap You, Chui Wei Bong ", Choon Weng Lee \\ Laboratory of Microbial Ecology, Institute of Biological Sciences, Faculty of Science, University of \\ Malaya, 50603 Kuala Lumpur \\ Institute of Ocean and Earth Sciences (IOES), University of Malaya, 50603 Kuala Lumpur \\ *Email: cwbong@um.edu.my (Corresponding author)
}

\begin{abstract}
Thirty three heterotrophic bacteria isolated from tropical coastal waters in Peninsular Malaysia were tested for susceptibility to 15 different antibiotics representing nine different classes of antimicrobial agents. We found that tetracycline, sulfonamide, mecillinam, sulfamethoxazole, erythromycin, and streptomycin resistance were predominant among the bacterial isolates. Resistance to chloramphenicol, ampicillin, vancomycin, norfloxacin, ofloxacin and trimethoprim/sulfamethoxazole were less common. All of the bacterial strains were susceptible to meropenem, imipenem, and ciprofloxacin. Approximately $70 \%$ of the isolates were resistant to two or more structural classes of antibiotic. Findings from this preliminary study indicated the prevalence of antibiotic resistance bacteria in the coastal waters of Penisular Malaysia.

ABSTRAK Kerentanan tiga puluh tiga bakteria heterotrofik yang diasingkan dari perairan pantai tropika di Semenanjung Malaysia telah diuji terhadap 15 antibiotik yang mewakili sembilan kelas agen antimikrobial. Kami mendapati bahawa ketahanan terhadap tetracycline, sulphonamide, mecillinam, sulfamethoxazole, erythromycin dan streptomycin adalah predominan di antara bakteria isolat. Resisten terhadap chloramphenicol, ampicillin, vancomycin, norfloxacin, ofloxacin dan trimethoprim/sulfamethoxazole adalah kurang lazim. Semua strain adalah peka terhadap meropenem, imipenem dan ciprofloxacin. Sekitar 70\% daripada bakteria strain adalah resisten terhadap dua atau lebih struktural kelas antibiotik struktural. Penemuan kajian preliminari ini menunjukkan kelaziman resistensi bakteria di perairan pantai Semenanjung Malaysia terhadap antibiotik.
\end{abstract}

(Keywords: marine bacteria, antibiotic, multidrug resistance, coastal waters)

\section{INTRODUCTION}

Antibiotics are used intensively and widely as medicines and growth promoters in agricultural industries. However, these chemical compounds receive little attention as pollutants in the aquatic environment [1]. The persistence and elevated concentrations of antibiotics pose some risks to the aquatic ecosystems, in particular microorganisms. Recent findings show that antibiotics can have deleterious impacts on denitrifying bacteria, eventually affecting the nitrogen cycle $[1,2]$. This initiated the idea that the persistence and elevated concentrations of antibiotics in environment could have the potential to disrupt biogeochemical processes in the biosphere.

Elevated concentration and persistence of antibiotics in aquatic ecosystems also generate new selective pressures on natural bacterial populations, and hence antibiotic-resistant bacteria are selected from the indigenous communities [3]. The high prevalence of indigenous antibiotic-resistant bacteria could present a potential health risk because the antibiotic resistance genes could be transferred to human microflora via food-borne or environmental bacteria $[4,5,6,7]$. The report by Dantas et al. [8] have also shown that environmental bacteria act as reservoir of antibiotic resistance genes and are a source of novel resistance genes for clinical pathogens.

Despite many studies to date that have examined the prevalence of antibiotic resistance in environmental bacteria and the mechanism of antibiotic resistance, studies from the aquatic environment in the South East Asia region are relatively scarce. As antimicrobial resistance genes and resistant bacteria in the environment are increasingly seen as an ecological problem $[9,10]$, there is a need to carry out this study. In this paper, we present preliminary data on 
antimicrobial susceptibility of bacteria isolated from coastal regions of Peninsular Malaysia.

\section{MATERIAL AND METHODS}

Bacterial strains were isolated in a previous study [11], from seawater obtained from different types of coastal environments along the
Straits of Malacca (estuarine waters at Klang $\left[03^{\circ} 00.1^{\prime} \mathrm{N}, 101^{\circ} 23.4^{\prime} \mathrm{E}\right]$; coastal waters at Port Dickson $\left[02^{\circ} 29.5^{\prime} \mathrm{N}, 101^{\circ} 50.3^{\prime} \mathrm{E}\right]$ ) and South China Sea (estuarine waters at Kuantan Stn 1 $\left[03^{\circ} 48.4^{\prime} \mathrm{N}, 103^{\circ} 20.6^{\prime} \mathrm{E}\right]$ and coastal waters at Kuantan Stn 2 [03 $\left.48.7^{\prime} \mathrm{N}, 103^{\circ} 22.4^{\prime} \mathrm{E}\right]$ ) (Figure 1).

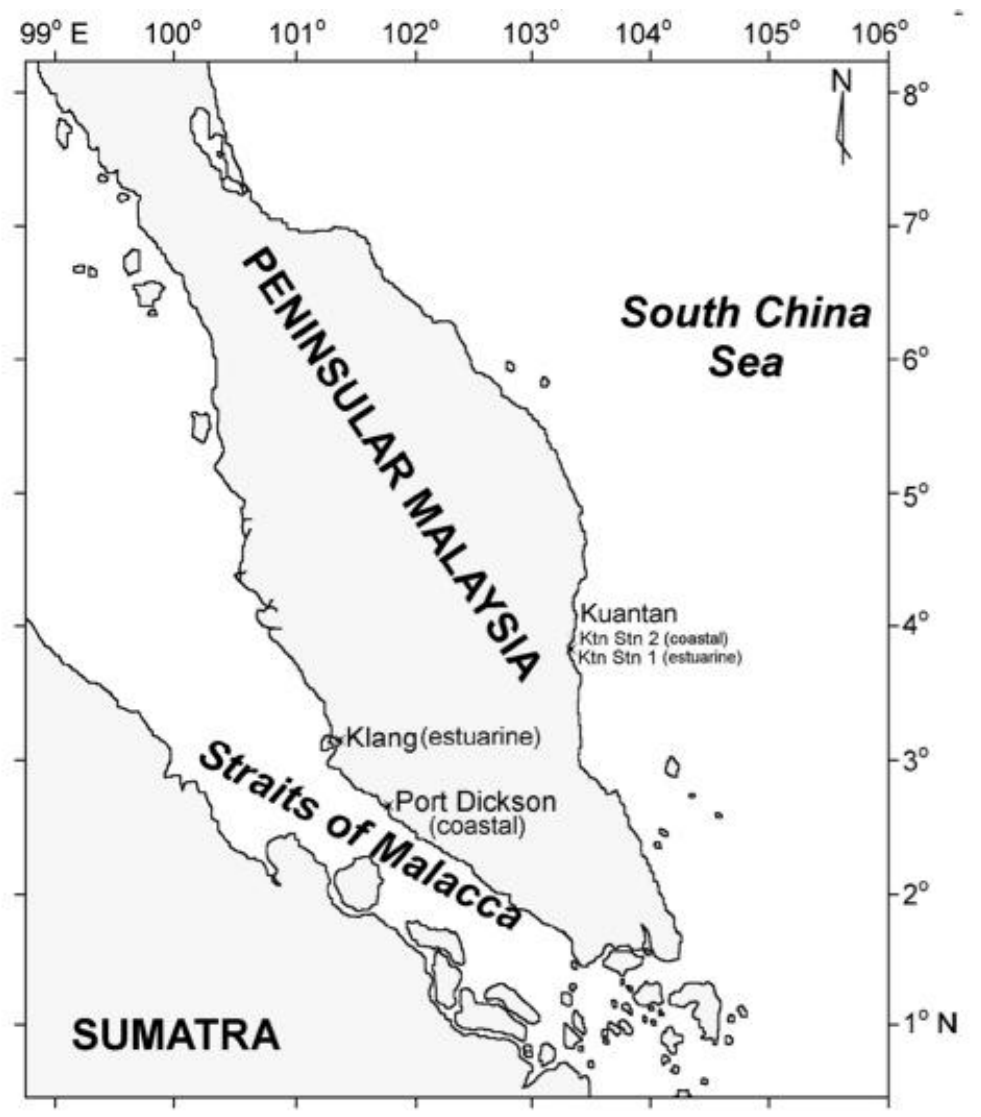

Figure 1: Map showing the location of the sampling stations in this study.

The bacterial isolation was carried out three times for each of the station sites. We randomly selected 33 isolates for antimicrobial susceptibility tests (Table 1). These isolates have been identified by phylogenetic analysis of their 16S rDNA gene sequences as shown in Table 2 [11]. The selected pure isolates were cultured onto marine broth 2216 (Difco) plus 1.5\% agar prior to transfer to nutrient broth amended with 2\% $\mathrm{NaCl}$. Susceptibility testing was performed in Mueller-Hinton agar (Difco, USA) with $2 \% \mathrm{NaCl}$ by using E-test method and disc diffusion method as described by the Clinical Laboratory Standards Institute [12]. The minimum inhibitory concentrations (MICs) of chloramphenicol (CL, 0.016-256 $\mu \mathrm{g} \mathrm{ml}^{-1}$ ), erythromycin (EM, 0.016-256 $\mu \mathrm{g} \mathrm{ml}^{-1}$ ), vancomycin (VA, 0.016-256 $\mu \mathrm{g} \mathrm{ml}^{-1}$ ), streptomycin (SM, 0.016-256 $\mu \mathrm{g} \mathrm{ml}^{-1}$ ), meropenem (MP, 0.002-32 $\mu \mathrm{g} \mathrm{ml}^{-1}$ ), imipenem (IP, 0.002-32 $\mu \mathrm{g} \mathrm{ml}^{-1}$ ), ampicillin (AM, 0.016-256 $\mu \mathrm{g} \mathrm{ml}^{-1}$ ), ciprofloxacin (CI, 0.002-32 $\mathrm{g} \mathrm{ml}^{-1}$ ), ofloxacin (OF, 0.002-32 $\mu \mathrm{g} \mathrm{ml}^{-1}$ ), norfloxacin (NX, 0.016-256 $\mu \mathrm{g} \mathrm{ml}^{-}$ ${ }^{1}$ ), sulfamethoxazole (SX, 0.064-1024 $\mu \mathrm{g} \mathrm{ml}^{-1}$ ), trimethoprim/ sulfamethoxazole (TS, 0.002-32 $\mu \mathrm{g} \mathrm{ml}^{-1}$ ) were determined by Etest (AB Biodisk, Sweeden) while the MICs of mecillinam (MEL 10, 10 $\mu \mathrm{g}$ ) and compound sulphonamides (S3 $\underline{300}, 300 \mu \mathrm{g}$ ) were determined by antibiotic discs (Oxoid) The vancomycin susceptibility testing was only performed against staphylococcal isolates. The inoculated E-test and discs plates were incubated overnight at $30^{\circ} \mathrm{C}$. MICs were measured according to the manufacturer's instruction. 
Table 1: List of bacteria isolated from different sampling sites.

\begin{tabular}{|c|c|c|}
\hline Station & Isolate & Strain \\
\hline \multirow[t]{9}{*}{ Port Klang } & PK2 & Stappia aggregata \\
\hline & $P K Q$ & Bacillus infantis \\
\hline & PKB & Pantoea agglomerans \\
\hline & PKD & Micrococcus sp. \\
\hline & PKP & Pseudoalteromonas sp. \\
\hline & PKC & Bacillus sp. \\
\hline & PKV & Microbulbifer sp. \\
\hline & $\mathrm{PKO}$ & Alteromonas sp. \\
\hline & PKT & Staphylococcus sp. \\
\hline \multirow[t]{3}{*}{ Port Dickson } & PD1H & Bacillus sp. \\
\hline & PD2M & Pseudoalteromonas viridis \\
\hline & PD2F & Pseudomonas aeruginosa \\
\hline \multirow[t]{4}{*}{ Kuala Sepetang } & MR3 & Vibrio sp. \\
\hline & MT3 & Halomonas sp. \\
\hline & T1G & Vibrio harveyi \\
\hline & SW1 & Micrococcus sp. \\
\hline \multirow[t]{4}{*}{ Kuantan } & KK10 & Bacillus megaterium \\
\hline & KK5 & Shewanella sp. \\
\hline & $\mathrm{K} 129$ & Escherichia coli \\
\hline & KD41 & Escherichia coli \\
\hline \multirow[t]{3}{*}{ Straits of Malacca } & SMB & Bacillus neonatiensis \\
\hline & SMSTAR & Bacillus sp. \\
\hline & SMN & Acinetobacter junii \\
\hline \multirow[t]{3}{*}{ Redang Island } & R2 & Salinimonas chungwhensis \\
\hline & R4 & Alteromonas sp. \\
\hline & R5 & Alteromonas alvinellae \\
\hline \multirow[t]{7}{*}{ Langkawi Island } & $\overline{L G N}$ & Microbulbifer maritimus \\
\hline & LGT & Staphylococcus pasteuri \\
\hline & LGA & Micrococcus luteus \\
\hline & LGV & Bacillus subtilis subsp. subtilis \\
\hline & LGM & Bacillus licheniformis \\
\hline & LGP & Staphylococcus cohnii \\
\hline & LGO2 & Brevibacterium casei \\
\hline
\end{tabular}

In the case of oxytetracycline (OTC), the MIC was determined using the 96 well microbroth dilution method [12]. Isolates were grown in nutrient broth amended with $2 \% \mathrm{NaCl}$ at $30^{\circ} \mathrm{C}$. For use as an inoculums, cell suspension of each isolate was adjusted to an optical density (OD) of 0.5 at $625 \mathrm{~nm}$. Twenty microliter of the bacterial suspension was inoculated into triplicate wells which contained $180 \mu \mathrm{l}$ Mueller Hinton broth (Difco) amended with $2 \% \mathrm{NaCl}$ and with twofold serial dilutions of OTC. The inoculated microtiter plates were incubated for 24 hours at $30^{\circ} \mathrm{C}$. The MIC was determined as the minimum antimicrobial dilution at which no bacterial growth occurred. Escherichia coli AG1 was used as a control in this study. 


\section{RESULTS}

We examined the susceptibility of the 33 marine bacteria to 15 antibiotics which representing 9 different classes of antimicrobial agents. Of them, high frequencies of resistance were observed for oxytetracycline (57.6\%), compound sulfonamides $(51.5 \%)$, mecillinam $(45.5 \%)$, sulfamethoxazole (33.3\%), erythromycin
(24.2\%) and streptomycin (21.2\%), whereas resistance to chloramphenicol (12.1\%), norfloxacin (12.1\%), ampicillin (6.1\%), trimethoprim/sulfamethoxazole (6.1\%), ofloxacin $(3 \%)$ were rare. All strains were susceptible to meropenem, imipenem and ciprofloxacin. The three Staphylococcus strains in this study were all susceptible to vancomycin (Figure 2).

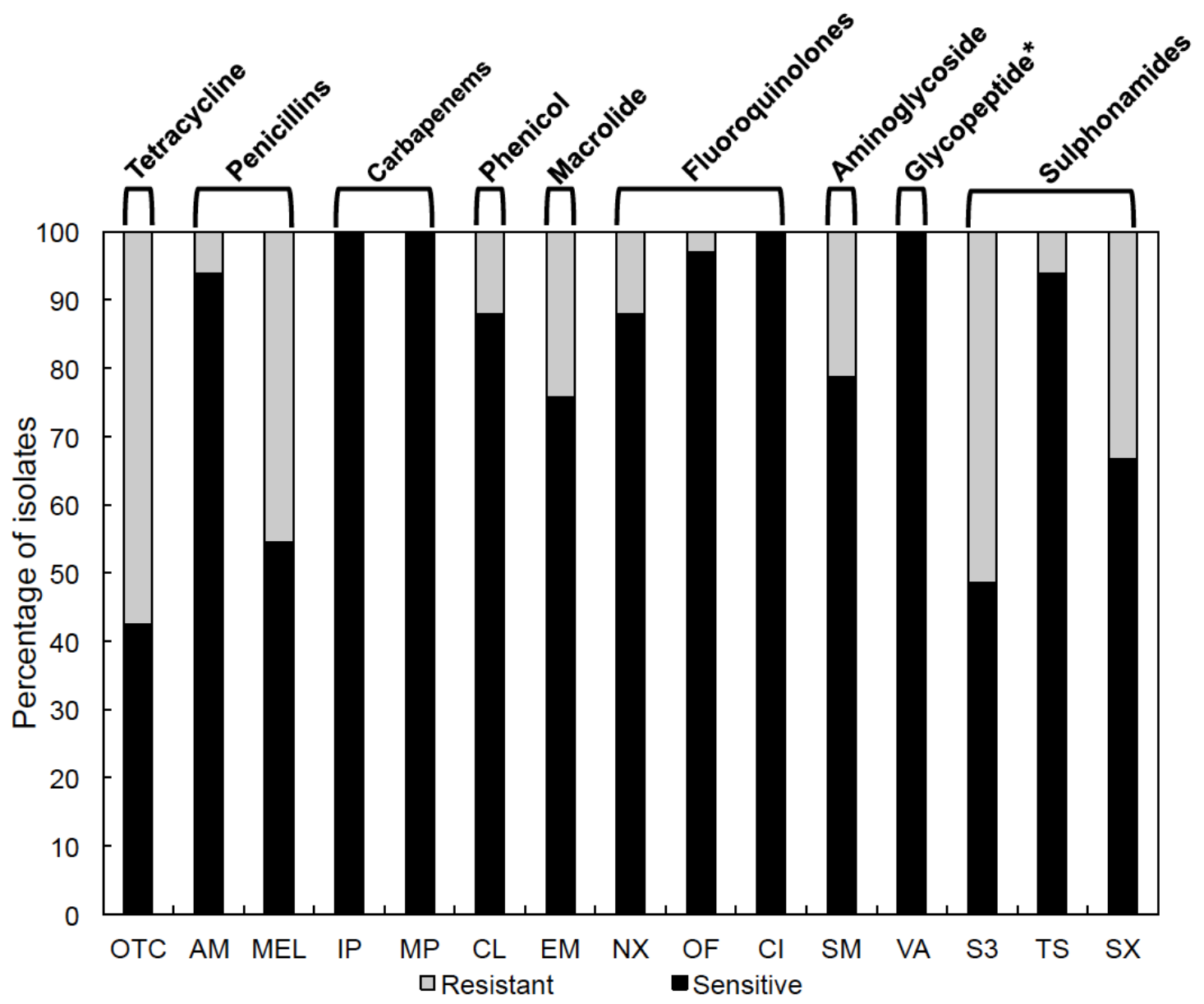

*: only Gram positive bacteria (Staphylococcus haemolyticus, Staphylococcus cohnii and Staphylococcus pasteuri) were tested.

Figure 2: Frequency of resistance to 15 antibiotics among the bacteria isolated from tropical coastal waters in Peninsular Malaysia.

Table 2 shows the antibiotic resistance profile of 33 strains of marine bacteria. Twenty four distinct antibiotic resistance patterns were observed. Approximately $70 \%$ of the bacteria were resistant to more than one structural class of antibiotic. Two bacteria $(6 \%)$ were found to have resistance to five antibiotics and five bacteria (15.2\%) were resistant to six antibiotics. Only $15.2 \%$ were sensitive to all antibiotics, and none of the bacteria were resistant to all antibiotics tested here. 
Table 2: Antimicrobial resistance profile of the bacterial isolates from coastal waters.

\begin{tabular}{|c|c|c|c|}
\hline No. antibiotic classes & Isolate & Strain & Resistance \\
\hline \multirow[t]{5}{*}{0} & KK10 & Bacillus megaterium & - \\
\hline & PD1H & Bacillus sp. & - \\
\hline & PD2M & Pseudoalteromonas viridis & - \\
\hline & PK2 & Stappia aggregata & - \\
\hline & $P K Q$ & Bacillus infantis & - \\
\hline \multirow[t]{5}{*}{1} & R5 & Alteromonas alvinellae & OTC \\
\hline & SMB & Bacillus neonatiensis & OTC \\
\hline & PD2F & Pseudomonas aeruginosa & MEL \\
\hline & KK5 & Shewanella sp. & MEL \\
\hline & LGN & Microbulbifer maritimus & S3 \\
\hline \multirow[t]{7}{*}{2} & PKB & Pantoea agglomerans & OTC, S3 \\
\hline & T1G & Vibrio harveyi & OTC, S3 \\
\hline & LGA & Micrococcus luteus & отC, S3, SX \\
\hline & PKD & Micrococcus sp. & EM, S3 \\
\hline & PKT & Staphylococcus sp. & MEL, EM \\
\hline & LGV & Bacillus subtilis subsp. subtilis & MEL, SM \\
\hline & PKP & Pseudoalteromonas sp. & MEL, S3 \\
\hline \multirow[t]{9}{*}{3} & LGM & Bacillus licheniformis & AM, EM, S3, \\
\hline & PKC & Bacillus sp. & MEL, EM, S3 \\
\hline & SMN & Acinetobacter junii & оTC, SM, S3, sX \\
\hline & MT3 & Halomonas sp. & OTC, NX, SM \\
\hline & PKV & Microbulbifer sp. & OTC, MEL, OF \\
\hline & LGP & Staphylococcus cohnii & OTC, MEL, S3, SX \\
\hline & PKO & Alteromonas sp. & OTC, MEL, S3, TS, SX \\
\hline & $\mathrm{KI} 29$ & Escherichia coli & OTC, EM, SX \\
\hline & KD41 & Escherichia coli & OTC, EM, SX \\
\hline \multirow[t]{3}{*}{4} & R2 & Salinimonas chungwhensis & OTC, AM, MEL, CL, S3, SX \\
\hline & R4 & Alteromonas sp. & OTC, MEL, SM, NX \\
\hline & LGT & Staphylococcus pasteuri & OTC, MEL, SM, S3, SX \\
\hline \multirow[t]{4}{*}{5} & MR3 & Vibrio sp. & OTC, MEL, NX, SM, S3, SX \\
\hline & SMSTAR & Bacillus sp. & OTC, MEL, CL, SM, S3, SX \\
\hline & LGO2 & Brevibacterium casei & OTC, MEL, CL, NX, S3, SX \\
\hline & SW1 & Micrococcus sp. & OTC, CL, EM, SM, S3, SX \\
\hline
\end{tabular}

OTC: oxytetracycline; MEL: mecillinam; S3: sulphonamides; SX: sulfamethoxazole; EM: erythromycin; AM: ampicillin; EM: erythromycin; SM: streptomycin; NX: norfloxacin; OF: ofloxacin; TS: Trimethoprim/sulfamethoxazole; CL: chloramphenicol

The distribution of MICs values of the antibiotic (except mecillinam and compound sulfonamides) against the 33 marine bacteria are shown in Table 3. According to the microbiological criterion proposed by Turnidge and Paterson [13], isolates in the higher range of MICs should be considered to have acquired resistance. Therefore the MICs of carbapenem antibiotics (imipenem and meropenem), fluoroquinolone antibiotics (ciprofloxacin and ofloxacin) and vancomycin in this study showed a monomodal (or absence of acquired resistance) distribution of susceptibility with ranges of 0.002 to $6 \mu \mathrm{g} \mathrm{ml}^{-1}$ to both carbapenems and fluoroquinolones whereas susceptibility to vancomycin ranged from 0.75 to $3 \mu \mathrm{g} \mathrm{ml}^{-1}$. In contrast, a bimodal (or acquired resistance) distribution was seen for trimethoprim/sulfamethoxazole, ampicillin, chloramphenicol, erythromycin, norfloxacin, streptomycin, sulfamethoxazole and oxytetracycline. 
Table 3: Distribution of minimal inhibitory concentration (MIC) of antibiotics (except for mecillinam and compound sulfonamides) used in this study.

\begin{tabular}{|c|c|c|c|c|c|c|c|c|c|c|c|c|c|c|c|c|c|c|c|c|c|c|c|c|c|c|c|c|c|c|}
\hline & & & & & & & & & & & & & & ber of iso & bates with & $\operatorname{hMIC}(\mu g$ & $\left.\mathrm{g} \mathrm{m}^{-1}\right)$ of & & & & & & & & & & & & & \\
\hline $\begin{array}{l}\text { Antibioitic } \\
\end{array}$ & 50.002 & 0.003 & 0.004 & 0.006 & 0.008 & 0.012 & 0.016 & 0.023 & 0.032 & 20.047 & 0.064 & 0.094 & 40.125 & 0.19 & $0.25 \quad 0$ & 0.38 & 0.50 & 0.75 & 1 & 1.5 & 2 & 3 & 4 & 6 & 8 & 12 & 16 & 24 & 32 & 232 \\
\hline Ciprofloxacin (Cl) & 1 & & & & & 1 & 2 & & & 3 & 10 & 2 & 2 & 3 & 1 & 1 & 3 & 1 & 2 & 1 & & & & & & & & & & \\
\hline Imipenem (IP) & & & & & & 2 & & 1 & 1 & 4 & 12 & 5 & 3 & & & 1 & 1 & & & & & 3 & & & & & & & & \\
\hline Meropenem (MP) & & & & & 1 & & & 1 & 1 & 1 & 4 & 5 & 12 & 3 & 1 & 1 & & & 1 & & & 1 & & 1 & & & & & & \\
\hline Ofoxacin (OF) & & & 1 & & & & & & & & 3 & 2 & & 11 & 3 & 1 & & 5 & 1 & 2 & 3 & & 1 & & & & & & & \\
\hline Trimethoprim/sulfamethoxazole (TS & & 1 & & 1 & 1 & 6 & 5 & 3 & 6 & 2 & 3 & & 1 & & 1 & & & 1 & & & & & & & & & & & & 2 \\
\hline & 50.016 & 0.023 & 0.032 & 0.047 & 0.064 & 0.094 & 0.125 & 0.19 & 0.25 & 0.38 & 0.5 & 0.75 & 1 & 1.5 & 2 & 3 & 4 & 6 & 8 & 12 & 16 & 24 & 32 & 48 & 64 & 96 & 128 & 192 & 256 & 2256 \\
\hline Norfloxacin (NX) & 1 & & & & & 2 & 1 & & 4 & 8 & 2 & 3 & 2 & 1 & & 2 & 2 & 1 & 1 & 1 & 1 & & 1 & & & & & & & \\
\hline Ampicillin (AM) & & 1 & & 1 & 1 & 6 & 5 & 3 & 6 & 2 & 3 & & 1 & & 1 & & & 1 & & & & & & & & & & & & 2 \\
\hline Chloramphenicol (CL) & & & & & & & & & 1 & 1 & 3 & 3 & 7 & 7 & 5 & & 1 & & 1 & & 2 & 1 & 1 & & & & & & & \\
\hline Eythromycin (EM) & 1 & 1 & & 1 & 3 & 4 & 7 & 5 & 1 & 2 & & & & 2 & & 1 & 1 & & 1 & & & 1 & & & 1 & 1 & & & & \\
\hline & 50.064 & 0.094 & 0.125 & 0.19 & 0.25 & 0.38 & 0.5 & 0.75 & 1 & 1.5 & 2 & 3 & 4 & 6 & 8 & 12 & 16 & 24 & 32 & 48 & 64 & 96 & 128 & 192 & 256 & 384 & 512 & 768 & 1024 & 21024 \\
\hline Streptomycin (SM) & & & & & & & & & & & & & 1 & 3 & 11 & 2 & 4 & 5 & & 1 & 1 & & & & & & & & & 1 \\
\hline Sulfamethoxazole (SX) & & & & & & & & & & 2 & 2 & 5 & 4 & & 1 & 3 & 1 & & & 1 & & & & & & & & & & 11 \\
\hline & $s 2$ & 4 & 8 & 16 & 32 & 64 & 128 & 2128 & & & & & & & & & & & & & & & & & & & & & & \\
\hline Oxytetracycline (OTC) & 12 & 2 & & 3 & 1 & 2 & 2 & 1 & & & & & & & & & & & & & & & & & & & & & & \\
\hline
\end{tabular}




\section{DISCUSSION}

Coastal areas are known to serve as "recipient" for most forms of anthropogenic contaminants including antibiotics. Rampant and unregulated use of antibiotics in clinical and agricultural practices pose risks to aquatic ecosystems and human health due to the antibiotic selective pressure and development of bacterial resistance. Although no measurement on antibiotic concentration was carried out in this study, the differences in percentage of bacterial resistance to various antibiotics could reflect the antibiotic contamination in this region and could be considered as a bioindicator to initiate monitoring programs for antibiotic pollution [14, 38].

In this study, a high percentage of marine bacteria were found resistant to oxytetracycline, compound sulfonamides and sulfamethoxazole. These three antibiotics have been commonly used in marine aquaculture and livestock treatments $[15,16]$. Of these three, oxytetracycline is by far the most widely used antibiotic. Our study suggests the presence of veterinary antibiotics in the Malaysia coastal environments that, often occurs as a results of unregulated use of these antibiotics in aquacultures [15,17].Our findings are also consistent with previous research on the prevalence of oxytetracyline, sulfonamides and sulfamethoxazole resistance bacteria isolated from different aquatic systems in Korea, Thailand and Vietnam $[6,18,19,20]$. Generally, the oxytetracycline resistance frequency in our study was lower than Dang et al. (2007) (92.996.1\%) and Li et al. (2010) (86.2\%). In contrast to oxytetracycline, sulfonamides and sulfamethoxazole resistance frequency in our study was higher than Hoa et al. [19,20].

Mecillinam is a $\beta$-lactam antibiotic commonly used in the treatment of urinary tract infections. Resistance to mecillinam is common in clinical isolates [22,23]. However, report of mecillinam resistance in environmental isolates is still relatively rare. There is only one study which was done by Neela et al. [24] have reported the mecillinam resistance in $78 \%$ of their isolated Vibrio species from seawater at a coastal aquaculture site in Japan. In our study, we found that only $45.5 \%$ of our isolates showed high resistance to mecillinam. Besides mecillinam, our isolates also showed high frequency of resistance to erythromycin and streptomycin.
The resistance of marine isolates to erythromycin and streptomycin is expected as resistance to these antibiotics are commonly reported [18,25,26,27,28,37]. In addition, erythromycin resistance is common among the Gram negative bacteria, due to their intrinsic resistance [29].

In order to investigate the presence of multidrugresistant (MDR) bacteria we used 15 antibiotics which belonged to 9 different classes of antibiotics for the antimicrobial susceptibility test. These antibiotics are used in Malaysia aquaculture, livestock production and are of interest in human medicine $[15,30]$. We were able to observe 24 distinct patterns of resistance profiles. Of these, 23 isolates were resistant to more than one structural classes of antibiotic. Our results indicated the widespread multiantibiotic resistance among bacteria from the coastal waters of Peninsular Malaysia, suggesting antibiotic contamination in our waters. The incidence of multi-resistance in aquatic environments is often associated with the use of antibiotics [10,31,32,33].

Although it is likely that different species will have different modal MIC, the MICs distribution in this study was not constructed on a speciesby-species basis due to our small sample size. Our study showed that the MIC distributions for imipenem, meropenem, ciprofloxacin, ofloxacin and vancomycin were monomodal, indicating the absence of acquired resistance of our isolates to these antibiotics. In contrast, bimodal distributions were noted for trimethoprim/sulfamethoxazole, ampicillin, chloramphenicol, erythromycin, norfloxacin, streptomycin, sulfamethoxazole and oxytetracycline, indicating the isolates in this study has acquired resistance to these antibiotics. Antibiotic resistance in bacteria can either be intrinsic or acquired [34]. Although acquisition of antibiotic resistance was not determined in this study, numerous studies have shown that bacteria are ready to exchange genetic information in nature, allowing the transfer of different resistance mechanisms that are already present in the environment between bacteria $[35,36]$.

This is the preliminary report to demonstrate the wide occurrence of antibiotic resistance in bacteria isolated from coastal waters in Malaysia, and our results suggested a potential problem in the levels of antibiotic contamination. As the seas are inter-connected, our results could be 
extrapolated for the whole South-East Asia region, and warrants a more extensive study in the future.

\section{ACKNOWLEDGEMENT}

This work was financially supported by the University of Malaya (UM RG150/11 SUS).

\section{REFERENCES}

1 Costanzo, S.D., Murby, J. and Bates, J. (2005). Ecosystem response to antibiotics entering the aquatic environment. Marine Pollution Bulletin 51: $218-223$.

2 Kotzerke, A., Sharma, S., Schauss, K., Heuer, H., Thiele-Bruhn, S., Smalla, K., et al. (2008). Alterations in soil microbial activity and $\mathrm{N}$-transformation processes due to sulfadiazine loads in pig manure. Environmental Pollution 153:315-322.

3 Kümmerer, K. (2004). Resistance in the environment. Journal of Antimicrobial Chemotherapy 54: 311-320.

4 Furushita, M., Shiba, T., Maeda, T., Yahata, M., Kaneoka, A., Takahashi, Y., et al. (2003). Similarity of tetracycline resistance genes isolated from fish farm bacteria to those from clinical isolates. Applied and Environmental Microbiology 69: 53365342.

5 Yoo, M.H., Huh, M.D., Kim, E.H., Lee, H.H. and Jeong, H.D. (2003). Characterization of chloramphenicol acetyltransferase gene by multiplex polymerase chain reaction in multidrugresistant strains isolated from aquatic environments. Aquaculture 217: 11-21.

6 Kim, S.R., Nonaka, L. and Suzuki, S. (2004). Occurrence of tetracycline resistance genes tet( $\mathrm{M})$ and tet(S) in bacteria from marine aquaculture sites. FEMS Microbiology Letters 237: 147156.
7 Li, Z., Li, D., Zhang, Y., Yang, M., Liu, M., and Qi, R. (2010). Antibiotic resistance characteristics of environmental bacteria from an oxytetracycline production wastewater treatment plant and the receiving river. Applied and Environmental Microbiology 76(11): 3444-3451.

8 Dantas, G., Sommer, M.O.A., Oluwasegun, R.E. and Church, G.M. (2008). Bacteria subsisting on antibiotics. Science 320: 100-103.

9 Björkman, J.; Nagaev, I., Berg, O.G., Hughes, D. and Andersson, D.I. (2000). Effects of environment on compensatory mutations to ameliorate costs of antibiotic resistance. Science 287: 1479-1482.

10 Manjusha, S., Sarita, G.B., Elyas, K.K. and Chandrasekaran, M. (2005). Multiple antibiotic resistances of Vibrio isolates from coastal and brackish water areas. American Journal of Biochemistry and Biotechnology 1: 201-206.

11 Lee, C.W., Ng, A.Y.F., Narayanan, K., Sim, E.U.H. and Ng, C.C. (2009). Isolation and characterization of culturable bacteria from tropical coastal waters. Ciencias Marinas 35(2): 153167.

12 Clinical and Laboratory Standards Institute. Performance standards for antimicrobial susceptibility testing; Fifteenth informational supplement M100-S15. 14th Ed. CLSI, Wayne,PA, USA, 2005.

13 Turnidge, J. and Paterson, D.L. (2007). Setting and revising antibacterial susceptibility breakpoints. Clinical Microbiology Reviews 20(3): 391-408.

14 Al-Bahry, S.N., Mahmoud, I.Y., AlBelushi, K.I., Elshafie, A.E., Al-Harthy, A. and Bakheit, C.K. (2009). Coastal sewage discharge and its impact on fish with reference to antibiotic resistant enteric bacteria and enteric pathogens as bioindicators of pollution. Chemosphere 77:1534-1539. 
15 Arthur, J.R., Lavilla-Pitogo, C.R. and Subasinghe, R.P. (1996). Use of chemicals in aquaculture in Asia. In: Shariff, M., Nagaraj, G., Chua, F.H.C. \& Wang, Y.G. (eds). The use of chemicals in aquaculture in Malaysia and Singapore, May 20-22, 1996 Tigbauan: Southeast Asian Fisheries Development Center, p. 127-140.

16 Chee-Sanford, J.C., Mackie, R.I., Koike, S., Krapac, I.G., Lin, Y.F., Yannarell,A.C., et al. (2009). Fate and transport of antibiotic residues and antibiotic resistance genes following land application of manure waste. Journal of Environmental Quality 38: 1086-1108.

17 Reimschuessel, R., Stewart, L., Squibb, E., Hirokawa, K., Brady, T., Brooks, D., et al. (2005). Fish Drug Analysis-PhishPharm: A Searchable Database of Pharmacokinetics Data in Fish. AAPS Journal 7: 288-327.

18 Heepngoen, P., Sajjaphan, K., Ferguson, J.A. and Sadowsky, M.J. (2008). Genetic and physiological characterization of oxytetracyclineresistant bacteria from giant prawn farms. Journal of Microbiology and Biotechnology 18(2): 199-206.

19 Hoa, P.T.P., Nonaka, L., Viet, P.H. and Suzuki, S. (2008). Detection of the sull, sul2, and sul3 genes in sulfonamideresistant bacteria from wastewater and shrimp ponds of North Vietnam. Science of the Total Environment 405: 377-384.

20 Hoa, P.T.P., Managaki, S., Nakada, N., Takada, H., Anh, D.H., Viet, P.H., et al. (2010). Abundance of sulfonamideresistant bacteria and their resistance genes in integrated aquacultureagriculture ponds, North Vietnam.In:Hamamura, N.,Suzuki,S., Mendo,S., Barroso,C.M., Iwata,H., Tanabe,S. (eds).Interdisciplinary Studies on Environmental ChemistryBiological Responses to Contaminants. TERRAPUB, Tokyo, p. 15-22.
21 Dang, H., Zhang, X., Song, L., Chang, Y. and Yang, G. (2007). Molecular determination of oxytetracyclineresistant bacteria and their resistance genes from mariculture environments of China. Journal of Applied Microbiology 103: 2580-2592.

22 Anderson, J.D. (1977). Mecillinam resistance in clinical practice-a review. Journal of Antimicrobial Chemotherapy 3(Suppl. B): 89-96.

23 Hossain, M.A., Rahman, M., Ahmed, Q.S., Malek, M.A., Sack, R.B. and Albert, M.J. (1998). Increasing frequency of mecillinam-resistant Shigella isolates in urban Dhaka and rural Matlab, Bangladesh: a 6 year observation. Journal of Antimicrobial Chemotherapy 42: 99-102.

24 Neela, F.A., Nonaka, L. and Suzuki, S. (2007). The diversity of multi-drug resistance profiles in tetracyclineresistance Vibrio species isolated from coastal sediments and seawater. Journal of Microbiology 45: 64-68.

25 Baya, A.M., Barayton, P.R., Brown, V.L., Grimes, D.J., Russek-Cohene, E. and Colwell, R.R. (1986). Coincident plasmids and antimicrobial resistance in marine bacteria isolated from polluted and unpolluted Atlantic Ocean samples. Applied and Environmental Microbiology 51: 1285-1287.

26 Tendencia, E.A. and de la Peña, L.D. (2001). Antibiotic resistance of bacteria from shrimp ponds. Aquaculture 195: 193-204.

27 Chelossi, E., Vezzulli, L., Milano, A., Branzoni, M., Fabiano, M., Riccardi, G., et al. (2003). Antibiotic resistance of benthic bacteria in fish-farm and control sediments of the Western Mediterranean. Aquacuture. 219: 8397. 
28 Akinbowale, O.L., Peng, H. and Barton,M.D. (2006). Antimicrobial resistance in bacteria isolated from aquaculture sources in Australia. Journal of Applied Microbiology 100: 1103-1113.

29 Nikaido, H. (1998). Multiple antibiotic resistance and efflux. Current Poinion in Microbiology 1: 516-523.

30 Hughes, A.J., Ariffin, N., Huat, T.L., Abdul Molok, H., Hashim, S., Sarijo, J., et al. (2005). Prevalence of nosocomial infection and antibiotic use at a University Medical Center in Malaysia. Infection and Control and Hospital Epidemiology 26(1): 100-104.

31 Miranda, C.D. and Zemelman, R. (2002). Antimicrobial multiresistance in bacteria isolated from freshwater Chilean salmon farms. Science of the Total Environment 293: 207-218.

32 Matyar, F., Dincer, S., Kaya, A. and Colak, O. (2004). Prevalence and resistance to antibiotics in Gram negative bacteria isolated from retail fish in Turkey. Annals of Microbiology 54: 151-160.

33 Matyar, F., Kaya, A. and Dinçer, S. (2008). Antibacterial agents and heavy metal resistance in Gram-negative bacteria isolated from seawater, shrimp and sediment in Iskenderun Bay, Turkey. Science of the Total Environment 407(1): 279-285.

34 Courvalin, P. (2006). Antibiotic resistance: The pros and cons of probiotics. Digestive and Liver Disease 38: S261-S265.

35 Amábile-Cuevas, C.F. and Chicurel, M.E. (1992). Bacterial plasmids and gene flux. Cell 70: 189-199.

36 Salyers, A.A. and Amábile-Cuevas, C.F. (1997). Why are antibiotic resistance genes so resistant to elimination? Antimicrobial Agents and Chemotherapy 41: 2321-2325.
37 Jalal, K.C.A., Nur Fatin, U.T., Mardiana, M.A., Akbar John, B., Kamaruzzaman, Y. B., Shahbudin, S. and Muhammad Nor, O. (2010). Antibiotic Resistance Microbes in Tropical Mangrove Sediments, East Coast Peninsular Malaysia. African Journal of Microbiology Research 4 (8): 640-645.

38 Jalal, K.C.A., Akbar John, B., Kamaruzzaman, B.Y. and Kathiresan, K. (2012). Emergence of Antibiotic Resistant Bacteria from Coastal Environment - A Review. In: Marina, P. (ed.). Antibiotic Resistant Bacteria - A Continuous Challenge in the New Millennium. InTech, p.143-158. 